\title{
Janus Molecule I: Dichotomous Effects of COMT in Neuropathic vs Nociceptive Pain Modalities
}

\author{
S.K. Segall ${ }^{1}$, W. Maixner ${ }^{1}$, I. Belfer ${ }^{2}$, T. Wiltshire ${ }^{3}$, Z. Seltzer ${ }^{4}$, and L. Diatchenko ${ }^{*}, 1$ \\ ${ }^{1}$ Center for Neurosensory Disorders, University of North Carolina, Chapel Hill, NC, USA \\ ${ }^{2}$ Molecular Epidemiology of Pain Program, Department of Anesthesiology, University of \\ Pittsburgh, Pittsburgh, PA, USA \\ ${ }^{3}$ Eshelman School of Pharmacy, University of North Carolina, Chapel Hill, NC, USA \\ ${ }^{4}$ Department of Dentistry, University of Toronto, Toronto, Ontario, Canada
}

\begin{abstract}
The enzyme catechol-O-methyltransferase (COMT) has been shown to play a critical role in pain perception by regulating levels of epinephrine (Epi) and norepinephrine (NE). Although the key contribution of catecholamines to the perception of pain has been recognized for a long time, there is a clear dichotomy of observations. More than a century of research has demonstrated that increasing adrenergic transmission in the spinal cord decreases pain sensitivity in animals. Equally abundant evidence demonstrates the opposite effect of adrenergic signaling in the peripheral nervous system, where adrenergic signaling increases pain sensitivity. Viewing pain processing within spinal and peripheral compartments and determining the directionality of adrenergic signaling helps clarify the seemingly contradictory findings of the pain modulatory properties of adrenergic receptor agonists and antagonists presented in other reviews. Available evidence suggests that adrenergic signaling contributes to pain phenotypes through a $1 / 2$ and $\beta 2 / 3$ receptors. While stimulation of a 2 adrenergic receptors seems to uniformly produce analgesia, stimulation of $\alpha_{1}$ or $\beta$ receptors produces either analgesic or hyperalgesic effects. Establishing the directionality of adrenergic receptor modulation of pain processing, and related COMT activity in different pain models are needed to bring meaning to recent human molecular genetic findings. This will enable the translation of current findings into meaningful clinical applications such as diagnostic markers and novel therapeutic targets for complex human pain conditions.
\end{abstract}

\section{Keywords}

Adrenergic receptor signaling; COMT; intrathecal; nociception; neuropathic; pain; spinal cord

\section{INTRODUCTION}

COMT, a major metabolizing enzyme of catecholamines, has been strongly linked in several pain models in both rodents and humans. Recently, our group discovered a functional haplotype of murine Comt, the orthologous gene to COMT in humans and rats (termed + SINE [1], Comt ${ }^{B 2 i}$ [2], or the B allele [3]). Mouse strains of the $\mathrm{Comt}^{B 2 i}$ haplotype have increased enzymatic function [1]. Post-hoc analysis of inbred mouse data from the strain

*Address correspondence to this author at the Center for Neurosensory Disorders, University of North Carolina, Chapel Hill, NC, USA; Tel: (919) 843-2549; Fax: (919) 966-5339; segall@dentistry.unc.edu, lbdiatch@email.unc.edu. 
survey Heritability of Nociception series [4-6] confirmed the Comt ${ }^{B 2 i}$ haplotype to be genetically related to increased sensitivity to inflammatory conditions that evoke pain behaviors [1]. In these assays, the subcutaneous application of irritants capsaicin, formalin or bee venom elicited paw licking and/or shaking, and the administration of acetic acid or magnesium sulfate injected intraperitonealy evoked abdominal writhing. Thermal assays that show statistical significance effects included the hot plate and Hargreaves pawwithdrawal assays (see [6] for experimental details).

These findings are in line with human genetic studies. In humans, high and low COMT enzymatic activity haplotypes have been named accordingly with their association with experimental pain sensitivity: The high activity haplotype is termed $L P S$ for Low Pain

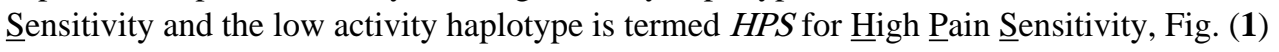
[7]. Consistent with these observations, we also showed that the systemic suppression of COMT activity, which increases catecholamine transmission, contributes to persistent pain states via the stimulation of $\beta_{2}$-and $\beta_{3}$-adrenergic receptors [8].

A perplexing problem regarding the relationship between low levels of COMT activity with clinical pain conditions and augmented sensitivity to noxious stimuli is the reported antiallodynic effects mediated by the administration of COMT inhibitors in various animal models [9-11]. While increasing adrenergic tone within the spinal cord is analgesic, increasing adrenergic stimulation in anatomical regions remote to the spinal cord may either increase or decrease pain processing in a manner that is stimulus modality dependent. From current existing findings, it appears that COMT activity evokes opposite effects on neuropathic pain and nociceptive/inflammatory pain: neuropathic pain is relieved by increasing catecholamine stimulation of adrenergic receptors. Nociceptive and inflammatory pain is relieved by decreasing catecholamine stimulation of adrenergic receptors in the periphery and increasing catecholamine stimulation within the spinal cord.

For the purpose of this Review, we have adopted the description of pain etiology as proposed by Scholtz and Woolf [12]. As such, the perception of pain can result from nociceptive, inflammatory, or neuropathic origins. Using examples of neuropathic and nociceptive pain we will present findings from animal and human studies that demonstrate the regional specificity of catecholamine signaling. In this review we will not discuss the effects of modulating of catecholamine signaling at supraspinal level. We will discuss findings based on three means of increasing or decreasing catecholamine transmission across pain modalities including 1) the examination of the effects of genetic background (including strain specific, knock-out and transgenic animal studies); 2) the effects of direct administration of catecholamines to peripheral and spinal sites; and 3) the effects of pharmacological manipulation of distinct catecholamines pathways with $a$ or $\beta$ adrenergic receptor agonists or antagonists. Table 1 lists agents or drugs discussed in this review.

\section{NOCICEPTIVE PAIN}

Nociceptive pain has as its primary biological function to warn an organism of impending or immediate threat of tissue damage. The physiological underpinnings of nociceptive pain have been extensively studied [13]. Nociceptive afferents (sensory neurons that convey information to the central nervous system) are stimulated by diverse noxious physical stimuli such a heat, cold, acid, and pressure [12]. These noxious stimuli activate sensory afferents that transmit neuronal signals to the spinal cord which then engage a large ascending and descending central nervous system network that shapes the sensory, affective, autonomic and motor responses to the noxious stimuli [12]. 


\section{A. Effects of Genetic Background on Nociceptive Pain}

Here we will discuss the genotypic effect of catecholamine metabolism by natural and engineered COMT functional haplotypes in animals and humans (Fig. 1).

\section{Genetic Contributions of Comt to Peripheral Nociceptive Pain in Animals-}

Evidence exists for the contribution of COMT genotype catecholamine levels to pain sensitivity in rat and mouse models. Comt knockout mice exhibit increased thermal pain sensitivity while transgenic mice expressing human COMT are more resistant to thermal pain [14]. Inbred strains of mice, which have a naturally occurring functional haplotype that increases COMT activity, $\mathrm{Comt}^{B 2 i}$, show increased tolerance to noxious thermal and chemical stimuli [1]. A positive correlation between nociceptive and inflammatory pain also strongly suggests a positive correlation between high COMT activity and decreased pain sensitivity to both types of stimuli that evoke pain.

Findings derived from various rat strains also show a correlation between high COMT activity and resistance to chemically-induced pain. Inbred Lewis-Wistar rats have approximately twice the COMT activity in liver lysates compared to inbred Fisher-344 rats, suggesting that functional COMT polymorphisms are also present in rats [15]. Lewis rats display decreased sensitivity to inflammatory pain (e.g., formalin test) [16]. Consistent with pain behavior of inbred mouse strains of the elevated $\operatorname{Comt}^{B 2 i}$ functional haplotype, Lewis rats show much less formalinevoked pain behaviors than Fisher-344 rats, which have lower COMT activity.

\section{Genetic Contributions of COMT to Human Experimental Pain-A common} SNP in COMT, rs4680 (vall58met), codes for the substitution of valine to methionine [17]. The met isoform of COMT shows less thermostability and activity in vitro [18-21]. Because a low activity allele should presumably lead to decreased catecholamine metabolism, a substantial number of genetic studies have attempted to link val158met to various diseases and pain conditions. In the first experimental human study to link the vall58met polymorphism with pain perception, hypertonic saline was infusion into the masseter muscle and pain measures were increased in individuals homozygous for the met allele polymorphism [22].

However, subsequent studies that have attempted to correlate val158met polymorphisms with pain susceptibility have yielded inconsistent results (reviews by [11, 23, 24]). Until recently, no mechanistic explanation has been advanced that relates lower enzymatic activity beyond the observation that reduced enzyme thermal stability is seen with the methionine substitution. Our group was the first to show that in addition to the contribution of rs4680, there are functional polymorphisms that constitute three major haplotypes in the human population, as opposed to only two major haplotypes. The val allele of rs4680, a guanine $(\mathrm{G})$, encodes for the most and least efficient enzyme. When taking into account these three haplotypes, individuals with $L P S$ and $H P S$ alleles can be separated so that an individual homozygous for the high pain sensitivity allele, who genotypes $\mathrm{G} / \mathrm{G}$ for the rs $4680 \mathrm{val}$, is not placed in the same genetic category as a person homozygous for the low pain sensitivity allele, who also genotypes $\mathrm{G} / \mathrm{G}$ for the rs $4680 \mathrm{val}$ allele. However, because the HPS frequency in Caucasian populations is relatively rare [7], this confounding effect is generally small.

In a recent review of the association of COMT polymorphisms with pain sensitivity, many experimental pain studies have confirmed an association between increased pain sensitivity with low COMT enzymatic based on the three functional haplotypes defined by Diatchenko [for review see 11]. Studies which used these haplotypes have been successful in relating $C O M T$ genotypes to aggregate measures of human pain sensitivity based on combined z- 
score measures of pressure pain thresholds, thermal pain thresholds, thermal tolerance, repeated measures of heat stimuli, and ischemic pain thresholds and tolerance [7]. Absolute measures of heat pain threshold and tolerance, repeated measures of heat stimuli, and pressure pain threshold [25], acute muscle pain from exercise (COMT genotype X pain catastrophizing scores) [26], or pain from exposure to a laser beam [27] have also been associated with these three haplotypes.

\section{Genetic Contributions of COMT to Human Musculoskeletal Pain Conditions}

-For more than forty years, it has been known that reduced levels of COMT activity in the periphery is associated with common musculoskeletal and orofacial pain conditions [28, 29]. Temporomandibular joint disorder, or TMD, is a painful condition of the temporomandibular joint and surrounding muscles and has been associated with the local production of inflammatory cytokines [30-33]. The low activity HPS allele has since been linked to post-operative pain [34], an increased risk of developing TMD [7], and in a recent case report, a TMD patient with high pain sensitivity was found to have a novel, nonsynonymous protein coding mutation within a critical region of COMT [35]. The clinical severity of fibromyalgia, a condition of widespread musculoskelfetal pain without apparent cause [36], has been correlated with the HPS haplotype in a Spanish cohort [37].

Even with the confounding variable of the rare HPS allele, low catecholamine metabolism associated with the met allele correlates with many musculoskeletal conditions. There are many more studies that have tested the genetic association with the vall58met polymorphism than studies that have based association on the three identified HPS, APS, and $L P S$ functional haplotypes. In general, it is consistently found that the low COMT activity met allele is associated with a higher risk of developing a painful condition. Met homozygotes also report an increased number of pressure points, and non-affected relatives of Israeli patients with fibromyalgia had a reduced frequency of the met COMT allele [38]. Similarly, met homozygotes have been shown to be enriched in two Brazilian fibromyalgia cohorts [39, 40], a Spanish fibromyalgia cohort [41], a Turkish cohort [42], and in an American cohort, met homozygotes experienced more pain on days when pain catastrophizing was higher compared to women with at least one val allele [43].

Other nociceptive pain conditions have been associated with the met allele. Osteoarthritis pain, which is can be considered a nociceptive pain evoked by mechanical stimuli [13], appears to be greater in Europeans with the low activity met allele [44]. In an Irish cohort, the development of postoperative pain following tooth extraction is greatest in individuals homozygous for the met allele [45]. Spanish women homozygous for the met allele also have greater pressure pain sensitivity, higher fatigue, and neck pain after surgery for breast cancer [46] and children homozygous for the met allele with chronic tension type headache have longer headache histories and greater pressure pain sensitivity [47].

4. Spinally-Mediated Nociceptive Pain-The thermally mediated tail-flick reflex is frequently used as a pain assessment assay that has been extensively used to study the pharmacodynamic properties of analgesics in rodents [48]. However, the tail-flick is a spinally-mediated reflex, which can occur following the transection of the spinal cord rostral to the lumbar region [49]. Thus, agents administered to the spinal space that modifies this reflex mediate the pharmacological effects at the spinal level. Other common thermal nociceptive assays that are frequently used to assess pain behavior and the analgesic properties of compounds are the hot plate and Hargreaves' tests. Unlike the tail-flick test, the behavioral endpoints (e.g., paw withdrawal to noxious heat) are dependent on more than a spinal reflex. Indeed, much of the confounding or seemingly contradictory findings can be explained by pointing out that the tail-flick is a spinally derived nociceptive response, and pain responses derived from peripheral injuries (paw or gut) result from the integration of 
complex neural networks associated with sensory afferents, spinal and supraspinal pathways [50]. This could be one explanation for the inverse effects of decreased catecholamine levels with regards to the tail-flick assays. Moreover, tail-flick data is in agreement with pain sensitivity by rodent strain (Fig. 2).

In classic inbred strains of mice, the latency to tail-flick is negatively correlated with COMT enzymatic activity such that strains with high COMT activity, which likely translate into lower levels of synaptic catecholamines, have shorter tail-flick latencies (i.e., more pain sensitive) than strains with low catecholamine metabolism [1]. The same pattern of tail-flick behavior is seen in the high COMT activity Lewis and low COMT activity Fisher rats: In comparison to Fisher rats, Lewis rats are significantly more sensitive (i.e. have shorter tailflick latencies) and vocalize more during the procedure compared to Fisher rats [16]. A third line of behavioral evidence to point to decreased sensitivity to tail-flick in low COMT activity rodent strains is found in an engineered S-COMT-deficient mouse line. S-COMTdeficient mice show no difference by sex or genotype in an array of nociceptive assays, with the exception of female mice in the tail-flick test [51]. Tail-flick latencies are longer in female S-COMT deficient mice compared to female wild-type mice $[10,11,51]$. This finding is in agreement with our hypothesis that higher basal levels of catecholamines in a genetically modified rodent will protect from spinally mediated pain.

\section{B. Administration of Catecholamines in Nociceptive Pain}

The majority of data on nociceptive pain and pharmacologic catecholamine manipulation of nociceptive pain are from animal studies. To decrease adrenergic signaling, catecholamines depleting agents or adrenergic antagonists are administered via drinking water or by injection into various anatomical sites (see Table 2). COMT inhibitors or adrenergic agonists are used both clinically and as pharmacological probes to stimulate adrenergic receptors and downstream signaling pathways. Here we will discuss the nociceptive effects of injecting Epi or NE locally into the spinal space (intrathecal administration) or to peripheral compartments with limited or no access to the brain.

\section{The Administration of Epi or NE to the Peripheral Compartments-Enhanced} pain sensitivity (behavioral signs of either allodynia or hyperalgesia as defined by IASP [52]) is observed in various rodent pain assays in response to the administration of catecholamines such as Epi and NE. The intradermal administration of NE produces enhanced pain sensitivity to mechanical stimuli [53-55] and the intradermal administration of Epi produces enhanced pain sensitivity to mechanical and thermal stimuli in rats [56-61].

Despite the use of Epi and NE to produce enhanced pain sensitivity, Epi is a common vasoconstrictor used in conjunction with numbing agents to concentrate injected local analgesics. However, Epi is not used by itself for local anesthesia [62]. Healthy human subjects report a mild, shortlasting pain following intradermal injections of Epi into the leg [63], and in another report, the infusion of Epi by a catheter inserted into the elbow evoked a slight increase in pain due to electrical stimulation and a decrease in heat pain tolerance in healthy subjects [64]. Intradermal administrations of NE are also reported to be painful and produce thermal hyperalgesia, particularly if the skin is previously sensitized [65-67]. Furthermore, endogenous high levels of NE and Epi have been correlated with stress and pain in human subjects. High levels of NE, as determined by urinary NE excretion rate, correlate with musculoskeletal pain and work stress in male subjects [68] and Epi and NE levels are higher in female nurses reporting back pain and stressful work events [69].

2. The Spinal Application of Epi or NE-When administered intrathecally, Epi produces analgesia in rats $[70,71]$ and increases nociceptive thresholds to noxious heat in 
spinally transected cats [72]. Intrathecal administration of NE also produces increases the latency to response to noxious heat in both the hot plate and tail-flick assays [73-75] and to noxious tail pinch [76]. The intrathecal administration of NE also produces a spinally mediated analgesia in rats and cats [75]. Furthermore, Epi has long been commonly used clinically to enhance spinal anesthesia in humans [77-79]; The epidural administration of Epi prolongs the anesthetic effects of co-administered tetracaine or lidocaine [80, 81].

Another method to increase catecholamine levels within the spinal cord is to implant tissues or cells that generate catecholamines. Transplantation of adrenal chromaffin tissue from the adrenal glands of the rat [82] or cow [83] into the subarachnoid space of rat spinal cord reduces thermal sensitivity compared to control animals. Conversely, depletion of spinal cord NE by the intrathecal injections of neurotoxins results in a decrease in hot-plate latencies [74] and produces hyperalgesia in the tail-flick assay [84].

\section{Pharmacological Modulation of Catecholamines and Nociceptive Pain}

1. Effects of Systemically Administered COMT Inhibitors and Catecholamine Depleting Agents on Nociceptive Pain-COMT inhibitors increase catecholamine signaling by decreasing the metabolism of catecholamines and the systemic administration of these inhibitors have been shown to increase sensitivity to noxious stimuli in animal models. In nociceptive and acute inflammatory pain, the systemic administration of COMT inhibitors peripheral to the spinal cord produce pharmacodynamic effects that mimic those produced by the peripheral administration of Epi and NE. The systemic administration of COMT inhibitors to rats $[7,8]$ and mice [11] induce mechanical and thermal hyperalgesia. These results are one more line of evidence of enhanced nociceptive pain sensitivity with increased peripheral catecholamine levels. The opposite effect, decreased nociceptive pain sensitivity, has been reported with catecholamine depleting agents.

Catecholamine signaling may be reduced by the removal or destruction of sympathetic nerve terminals that release catecholamines. Thus, chloroform-induced hyperalgesia in rodents can be prevented by surgical sympathectomy, or chemical sympathectomy with catecholamine depleting agent 6-OHDA [53]. However, in contrast to this analgesic properties of 6-OHDA [53], intrathecal injections of 6-OHDA produces hyperalgesia when assessed with $n$ nociceptive stimuli $[84,85]$. The contrasting effects of 6-OHDA on nociceptive evoked pain are in agreement with our hypothesis that enhanced catecholamine transmission in the spinal cord is analgesic while enhanced transmission at the level of peripheral primary afferents is hyperalgesic (Fig. 1). Adrenergic agonists and antagonists follow this general pattern.

\section{Effects of Adrenergic Agonists and Antagonists in Nociceptive Pain-Five} major groups of adrenergic receptors have been identified: $\alpha_{1}, a_{2}, \beta 1, \beta_{2}$, and $\beta_{3}$, reviewed by [86]. These receptors are $\mathrm{G}$ protein-coupled receptors, which bind extracellular endogenous agonists NE and Epi, resulting in the activation of specific signal transduction pathways. Fig. (2) shows the effects of adrenergic receptor ligands on nociceptive and neuropathic pain. The general pattern observed is that the spinal cord activation of $a_{1 / 2}$, or $\beta_{2 / 3}$ adrenergic receptors decrease pain sensitivity (Fig. 2). At sites remote from the spinal cord, the effect depends on receptor subtype.

3.1. Adrenergic Agonists in Nociceptive Pain: As we have discussed previously, increasing catecholamine levels outside of the spinal cord increase sensitivity to nociceptive stimuli: $a_{1}$-agonists applied systemically or cutaneously also increase pain sensitivity. Cutaneous injections of the selective $a_{1}$-agonist phenylephrine produce thermal hyperalgesia in mice [87] and augment pain behaviors when co-injected with a ligand for $\mathrm{P} 2 \mathrm{X}_{3}$ in non-injured rats [88]. In healthy human participants, the cutaneous ionophoresis of 
the selective $a_{1}$-agonist phenylephrine produces thermal hyperalgesia in normal skin [89] and pain in mildly injured skin was attenuated by the $a_{1^{-}}$antagonist terazosin [90]. These effects show stimulation of the $a_{1}$ receptor to be similar to the effect of systemic, intradermal or intrathecal NE.

While we have found only a few reports on the hyperalgesic effects of peripherally applied $a_{1}$ agonists, there is extensive literature on the analgesic properties of peripherally applied $a_{2}$ agonists [reviewed by 91; Fig. 2]. This analgesic effect of $a_{2}$ agonists is blocked or reversed by $a_{2}$ antagonists [73,74, 87, 92-98]. The opposing effects of $a_{1}$-agonists, which increase pain sensitivity outside of the spinal cord, and $a_{2}$-agonists, which are analgesic, exemplify an adrenergic receptor subtype specificity to pain transmission.

While $a_{1}$ or $a_{2}$ agonists may increase or decrease pain outside of the spinal cord, the stimulation of both $a$-adrenergic receptors within the spinal cord decreases sensitivity to multiple modalities of nociceptive pain. Intrathecally administered $a_{2}$-adrenergic agonists such as clonidine, dexmedetomidine, ST-91, tizanidine, and PT-31 [54] produce antinociceptive effects to a variety of noxious stimuli $[76,74,97,99-103]$. The $a_{1^{-}}$ adrenergic agonists phenylephrine [73, 75], oxymetazoline [73, 104, 105] and methoxamine $[74,98]$ produce analgesia when applied intrathecally, although one study did not observe an analgesic effect of methoxamine [97]. We have not been able to find references in the literature of $\alpha_{2}$ agonists promoting nociception when applied peripherally or intrathecally. Furthermore, in our search for effects of agonists in nociceptive pain, we found two reports of a $\beta$-adrenergic agonist isoproterenol, which had no effect on nociception with intrathecal application [75,97], yet increased mechanical and ischemic pain in intradermal and intravenous injections $[56,106]$ (Table $\mathbf{1}$ ).

3.2. Adrenergic Antagonists in Nociceptive Pain: Consistent with our hypothesis, the intrathecal administration of $a_{1}$ receptor antagonists produce increased pain sensitivity, while administration of the $a_{1}$ receptor antagonists to the peripheral sites remote to the spinal cord is analgesic in the nociceptive models (Fig. 2). Selective $a_{1}$-antagonists are analgesic with intradermal or systemic application. Intra-arterial administration of the $a_{1^{-}}$ antagonist terazosin attenuates the enhanced response of $\mathrm{C}$ - fibers evoked by interdermal injections of capsaicin in rat [107]. Intra-plantar injections of terazosin also inhibit the hyperalgesia produced by a $\mathrm{P} 2 \mathrm{X}_{3} / \mathrm{P} 2 \mathrm{X}_{2} / 3$ receptor agonist in rat [88] and in humans, terazosin has been shown to relieve pain in patients with ureteral stents [108].

Intraperitoneal administration of the selective $a_{1}$-antagonist prazosin reduces the number of body writhes induced by acetic acid in rats [109], Conversely, intrathecal administration of $a_{1}$-antagonists prazosin and WB 4101 produces thermal hyperalgesia in rats assessed with the tail flick assay [110], although several reports showed no effect of prazosin [74, 111, $112]$.

Consistent with the uniformly analgesic effects of intrathecal stimulation of either $a_{1}$ or $a_{2}$ receptors, the nonselective $a$-antagonists phentolamine increases sensitivity to noxious thermal stimuli when administered intrathecaly (Fig. 2) [110, 112, 113]. Other nonselective a-antagonists have no effect on baseline nociceptive threshold with intrathecal $[73,76,112$, $114]$ or intra-dermal $[53,114]$ administration. Generally, $a$-antagonists are used to characterize the analgesic site of action of $a_{1}$-agonists [74, 110,114] or $a_{2}$-agonists [73, 74, $98,115]$. However, it has been reported that the increased pain sensitivity induced by chloroform lesions is abolished by the intradermal injection of phentolamine, a nonselective $a$-antagonist, or by yohimbine, which is a relatively selective $a_{2}$-antagonists [53]. The analgesic-like behaviors produced with phentolamine can be explained by its ability to block $a_{1}$-receptors at peripheral sites remote to the spinal cord, which produce hyperalgesic effects. The analgesic properties associated with yohimbine might result from the blockade 
of serotonin receptors [116-118]. Thus, overall stimulation of $a_{2}$ adrenergic receptors uniformly produce analgesia and antagonists of $a_{2}$ receptors generally increase pain sensitivity in nociceptive pain models.

Unlike a receptors antagonists, $\beta$-agonists and antagonists seem to show uniform effects in nociceptive pain assays, although there is a paucity of findings of the effects of $\beta$-agonist on nociceptive pain. In contrast, there are many reports of $\beta$-antagonists administered remotely to the spinal cord, which is analgesic. Non-selective $\beta$-adrenergic receptor antagonists significantly attenuate nociceptive pain. For example, intradermal pretreatment with propranalol, a nonselective $\beta$-adrenergic antagonist, significantly attenuates epinephrineinduced hyperalgesia [56]. Intraperitoneal administration of propranalol blocks visceral nociception [109], and propranalol or combined $\beta_{2^{-}}$and $\beta_{3}$-adrenergic receptor antagonists block mechanical and thermal hyperalgesia associated with COMT enzyme inhibition [8]. Interperoneal administration of nadolol augments analgesia to thermal nociception [119] and the selective $\beta 1$ - antagonist metoprolol has been reported to attenuate visceral nociception [109]. Furthermore, systemically derived and administered Epi dependent hyperalgesia are blocked by both the non-selective $\beta$-antagonist propranalol and selective $\beta_{2}$ - antagonist ICI $118,551[60]$. There are two reports of the non-selective $\beta$ - antagonist propranalol administered intrathecally, (Fig. 2). Intrathecal propranalol prolonged spinal anesthesia [120] in one report and had no effect in another [114]. Intrathecal administration of the $\beta 1$ agonist isoproterenol had no effect in three reports [73, 75, 97] and intradermal administration increased pain sensitivity in two other reports $[56,106]$. Taken together, in nociceptive pain models, antagonism of $\beta$-receptors is analgesic. More research is needed to confirm the hyperalgesic effect of $\beta$-receptor agonists in nociceptive pain models.

Consistent with the effect of adrenergic drugs in nociceptive animal pain assays, $a_{2}$-agonists and $\beta_{2}$-antagonists produce analgesia in several human pain conditions. Thus, clinical pain is reduced by the nonselective $\beta$-antagonist propranalol in patients with fibromyalgia [121, 122] and TMD [121, 123], and the $\alpha_{2}$ agonist clonidine is prescribed for a variety of pain conditions [124]. Ischemic pain from angina is also antagonized following treatment with selective $\beta 1$-antagonists $[125,126]$.

\section{NEUROPATHIC PAIN}

Common diseases, injuries, and interventions can cause neuropathic pain as a result of damaging somatosensory pathways in the central and/or peripheral nervous system [127]. Unlike nociceptive pain, there is no discernable role for protection or repair in response to neuropathic pain; neuropathic pain results from nerve pathology and does not provide an adaptive protective warning regarding potential injury [12].

Given the multiple etiologies and case definition of neuropathic pain, a concise literature review on this topic is difficult [128]. Many painful conditions once considered neuropathic have now been redefined under the term Complex Regional Pain Syndrome. Neuropathic pain is distinguished from pain due to inflammation, musculoskeletal pain, and other types of pain that develop secondary to neuroplastic changes and the progression of neurologic disorders [13, 129-133]. Therefore our discussion of neuropathic pain will be limited to animal models that employ nerve injury as the causative insult used to produce subsequent behaviors that mimic human neuropathic pain states.

\section{A. Genetic Background Effects on Neuropathic Pain}

To date, there is very little data on the effect of COMT polymorphisms and function on the development of neuropathic pain. Lewis rats, which have greater COMT activity than Fisher-344 rats [15], express neuropathic pain behaviors for longer time periods and require 
longer recovery times following injury to the sciatic nerve when compared with Fisher-344 rats [134-136]. Mouse strains of the $\operatorname{Comt}^{B 2 i}$ haplotype, which is associated with increased COMT enzymatic activity, tend to show greater pain behaviors to nerve injury [1]. The only published study to date examining the relationship of COMT val158met and neuropathic pain in humans, found no correlation between COMT genotype and neuropathic pain [137].

\section{B. The Effects of Catecholamines on Neuropathic Pain}

To our knowledge there is no recent literature on the effects of spinal intrathecal injections of Epi or NE on experimental models of neuropathic pain; however, we have found numerous reports of spinal subarachnoid cavity adrenal chromaffin tissue grafts on neuropathic pain.

Transecting the sciatic and saphenous nerves in rats produces autotomy, a self mutilation behavior thought to reduce the perception of neuropathic pain [138]. Autotomy is reduced by $63 \%$ in rats spinally implanted with adrenal medulla tissue [139]. Similarly, rats treated with bovine chromaffin cell implants show reduced allodynia, hyperalgesia, and skin temperature abnormalities and the intrathecal delivery of the non-selective a-adrenergic receptor antagonist phentolamine partially attenuates these effects. Transplants of either embryonic rat or neonatal cow immortalized chromaffin cells also attenuate cold allodynia, and tactile and thermal hyperalgesia following chronic constriction in the rat [140]. More recently, bovine or porcine sources of chromaffin tissue were compared for efficacy in a rat following chronic constriction [141]. The authors found that transplants from porcine sources reduced mechanical and cold allodynia while transplants from bovine sources reduced only cold allodynia. The implantation of chromaffin cells from humans with renal cancer attenuates cold allodynia in rats with sciatic nerve injury [142]. In sum, spinal chromaffin transplants decrease neuropathic pain in a manner that is sensitive to antagonism with adrenergic antagonists.

\section{The Effects of Pharmacological Modulation of Catecholamines on Neuropathic Pain}

Neuropathic pain is relieved by pharmacological approaches that modulate catecholamine release, metabolism by COMT, and by treatments with $\alpha$ and $\beta_{2}$ adrenergic receptor agonists.

1. COMT Inhibition-The oral administration of the COMT inhibitor nitecapone reverses the mechanical and thermal hyperalgesia observed in streptozotocin-induced diabetic rats [9]. The effect of nitecapone on thermal and mechanical hyperalgesia is contrary to the effects of systemically administered COMT inhibitors described above on both thermal and mechanical pain sensitivity where COMT inhibition evokes a hyperalgesic response to both mechanical and thermal pain [8]. However, this seemingly contradictory "analgesic effect" also holds true for other neuropathic pain conditions evoked by nerve ligation [143] where the intraperitoneal administration of the COMT inhibitor nitecapone reverses the mechanical and cold allodynia produced by spinal nerve ligation. In addition, dorsal horn neuronal responses, to nociceptive $\mathrm{C}$-fiber stimulation is attenuated by the intravenous administration of the COMT inhibitor OR486 [10]. Thus, these animal studies demonstrated that the systemic inhibition of COMT, which presumably increases the bioavailability of catecholamines, produces an analgesiclike effect in response to peripheral nerve damage induced by injury or metabolic insults.

2. Adrenergic Agonists and Antagonists in Neuropathic Pain Models-A review of the literature shows that non-selective a-adrenergic receptor stimulation appears to contribute to neuropathic pain behaviors in a manner that mimics its effects on nociceptive pain: analgesic responses when nonselective $a$ - or $a_{1^{-}}$adrenergic receptors are blocked by 
antagonists in the periphery remote to the spinal cord (Fig. 2). For example, in rats with L5L6 spinal nerve ligations, the intraperitoneal administration of the non-selective $a-$ antagonist phentolamine reduce mechanical pain sensitivity [144, 145] and thermal sensitivity [146]. Intravenous administration of phentolamine suppresses nociceptor excitation, which is blocked by the selective $a_{1}$ - antagonist prazosin [147]. In human trials, patients with sympathetically maintained pain (SMP) report reduced thermal and mechanical sensitivity following the intravenous administration of phentolamine [148]; however significant analgesia in response to intravenously administered phentolamine was not observed in a later SMP clinical trail [149] or in a painful diabetic neuropathy trail [150]. Furthermore, the subcutaneous administration of the nonselective a-antagonist RS42206 has no effect on thermal or mechanical sensitivity in sciatic nerve transected mice [151].

The effect of selective $a_{1}$-adrenergic antagonist in neuropathic pain is similar to what is observed in nociceptive pain, but the literature is limited (Fig. 2). Intraperitoneal administration of the selective $a_{1}$ - antagonist prazosin [146, 152] and terazosin [144] decreased thermal and mechanical allodynia in neuropathic rats. However, in another report, intradermal administration of prazosin did not alleviate mechanical pain sensitivity in L5/L6 nerve ligated rats [153]. And, the selective $a_{1^{-}}$agonist phenylephrine enhances both nociceptive pain sensitivity and neuropathic pain in patients with post-herpetic neuralgia, although the cohort was very small (15 subjects) [154]. Decreased mechanical pain with intrathecal administration of the $a_{1^{-}}$agonist, oxymetazoline, in L5/L6 nerve damaged rats [115] has been reported; however, the preponderance of evidence shows $a_{1^{-}}$agonists to have no effect following intrathecal administration $[105,115,155,156]$.

While the literature on intrathecal or systemic/cutaneous administration of $a_{1^{-}}$agonists in neuropathic pain is incomplete, there is abundant literature on the analgesic affect of $a_{2^{-}}$ adrenergic receptor stimulation on neuropathic pain (Fig. 2). In L5-L6 nerve ligated rats, intrathecal administration of the $a_{2}$-agonist clonidine [95, 157], dexmedetomidine [92, 101, 115] fadolmidine [92], uinoxaline [115], radolmidine [101], and ST-91 [95, 115] reduced pain responses to noxious mechanical or thermal stimulation. In sciatic nerve injured rats, intrathecal clonidine [158] and tizanidine [159] reduce mechanical sensitivity and clonidine reduces thermal nociception in a pertussis toxin model of murine neuropathic pain [105]. Cutaneous or perineural administration of $a_{2}$-agonists are also analgesic in neuropathic pain. In L5-L6 nerve ligated rats, subcutaneous injections of dexmedetomidine [92], or clonidine [160] reduces pain sensitivity in response to noxious mechanical or thermal stimulation. In sciatic nerve injured rats, subcutaneously administered dexmedetomidine [151] or perineurally administered clonidine $[158,161-163]$ also reduce mechanical or thermal pain sensitivity. In human experimental studies, patients with painful diabetic neuropathy [150] or causalgia [63], show reduced thermal and mechanical sensitivity with a clonidine transdermal patch.

Systemic or intradermal $a_{2}$-agonists produce analgesia in neuropathic pain models while intrathecal $a_{2}$-antagonists have no effect [95] or increase thermal sensitivity in neuropathic animals [164]. However, it has been also reported that the $a_{2}$-antagonist yohimbine produces analgesia in neuropathic pain patients [149]. It is not clear if the analgesic effects of yohimbine are mediated by blocking $a_{2}$-receptors because this compound also has effects on serotonin receptors [116-118] and thus the observed analgesic effects could be mediated by receptors other than $a_{2}$-adrenergic receptors. Additionally, this study did not control for a placebo effect, which is necessary as clinical trials of analgesics often associate with strong responses to placebo, (for reviews, see [165]). In addition, the $a_{2}$-antagonist SKF-86466 also produces analgesia in a rodent neuropathic pain model [146] but the site of action in producing analgesia is unknown but may involve supraspinal structures [166]. In sum, our 
current knowledge points to the analgesic effects of $a_{2}$-adrenergic stimulation in neuropathic pain, just as occurs with nociceptive pain.

Findings regarding the role of $\beta$-adrenergic receptors in neuropathic pain are sparse. We did not find reports that examined the effects of intrathecal administration of $\beta$-agonists or $\beta$ antagonists on neuropathic pain. Systemic or cutaneous administrations of non-selective, or selective $\beta 1$ and $\beta 3$-agonists have no effect on neuropathic pain. In contrast to the systemic administration of $\beta_{2}$-agonists on nociceptive models, in neuropathic pain models, systemic $\beta_{2}$ stimulation relieves pain [167]. Intraperitoneal injections of a variety of $\beta_{2}$-agonists suppress mechanical allodynia following sciatic nerve constriction [167, 168]. Both intraperitoneal and intrathecal injections of the ( $\beta_{2}$-antagonist ICI 118,551 attenuate analgesia conferred by $\beta_{2}$-agonists following never injury, providing evidence of the analgesic effects of $\beta_{2}$-agonists on neuropathic pain [167].

A recent case study reported that the $\beta_{2}$-agonist salbutamol, produces a beneficial effect in a small cohort of neuropathic pain patients [169]. The authors noted that $\beta_{2}$ adrenergic agonist induced analgesia in neuropathic pain conditions seems to be contrary to the demonstrated beneficial analgesic effects of $\beta$-adrenergic antagonists in treating musculoskeletal pain conditions [169]. This statement falls in line with our theory that increased catecholamine levels are analgesic in neuropathic pain and produce a hyperalgesia to nociceptive and musculoskeletal pain.

\section{CONCLUSIONS}

In this Review, and to our knowledge, we are the first to compare and contrast the role of peripheral and spinal adrenergic signaling in modulating nociceptive and neuropathic pain. There appears to be a common adrenergic pain modulatory mechanism among vertebrate animals (i.e., cat, dog, rat, mouse, monkey, and human; Table 2). We propose that there is a fundamental difference in the effects of catecholamine transmission in spinal cord and peripheral nervous system that signals nociceptive information from skeletal muscle and skin (Fig. 1).

How then does one account for the contribution of catecholamines and COMT enzyme activity to different etiological sources of pain evoking stimuli? It appears from the available published data that neuropathic pain should be responsive to decreased catecholamine metabolism and increased adrenergic-receptor stimulation. Nociceptive, inflammatory and musculoskeletal pain in humans appears to be driven by peripheral adrenergic receptor stimulation; reducing this stimulation by adrenergic antagonists is analgesic. Although both adrenergic $\alpha_{1 / 2}$ and $\beta_{2 / 3}$ receptors seem to contribute to pain-related adrenergic signaling, COMT-dependent adrenergic signaling appears to be associated mostly with $\beta_{2}$ receptors. While stimulation of $a_{2}$ adrenergic receptor seems to uniformly produce analgesic effect, stimulation of $a_{1}$ or $\beta_{2}$ receptors may produce either analgesic or hyperalgesic effects (Fig. 2). We hypothesize that the fundamental difference between the contribution of COMT activity to neuropathic and nociceptive, musculoskeletal and inflammatory pain is driven by a $\beta_{2^{-}}$and possibly $a_{1}$ receptors mediated "switch". Further investigation of the directional effects of adrenergic signaling on the modulation and transmission of pain evoking stimuli resulting from multiple etiologies is needed to translate basic molecular genetic and behavioral findings into meaningful clinical findings that impact the treatment of complex human pain conditions. 


\section{ABBREVIATIONS}

COMT Catechol-O-methyltransferase

Epi Epinephrine

NE Norepinephrine

TMD Temporomandibular joint disorder

\section{REFERENCES}

1. Segall SK, Nackley AG, Diatchenko L, Lariviere WR, Lu X, Marron JS, Grabowski-Boase L, Walker JR, Slade G, Gauthier J, Bailey JS, Steffy BM, Maynard TM, Tarantino LM, Wiltshire T. Comt1 genotype and expression predicts anxiety nociceptive sensitivity in inbred strains of mice. Genes Brain Behav. 2010; 9(8):933-946. [PubMed: 20659173]

2. Kember RL, Fernandes C, bridge EM, Liu L, Paya- Cano JL, Parsons MJ, Schalkwyk LC. A B2 SINE insertion in the Comt1 gene (Comt1(B2i)) results in an overexpressing, behavior modifying allele present in classical inbred mouse strains. Genes Brain Behav. 2010; 9(8):925-932. [PubMed: 20618449]

3. Li Z, Mulligan MK, Wang X, Miles MF, Lu L, Williams RW. A transposon in comt generates mRNA variants and causes widespread expression and behavioral differences among mice. PLoS One. 2010; 59(8)(8):925-e12181.

4. Mogil JS, Wilson SG, Bon K, Lee SE, Chung K, Raber P, Pieper JO, Hain HS, Belknap JK, Hubert L, Elmer GI, Chung JM, Devor M. Heritability of nociception I: responses of 11 inbred mouse strains on 12 measures of nociception. Pain. 1999; 80(1-2):67-82. [PubMed: 10204719]

5. Mogil JS, Wilson SG, Bon K, Lee SE, Chung K, Raber P, Pieper JO, Hain HS, Belknap JK, Hubert L, Elmer GI, Chung JM, Devor M. Heritability of nociception II'Types' of nociception revealed by genetic correlation analysis. Pain. 1999; 80(1-2):83-93. [PubMed: 10204720]

6. Lariviere WR, Wilson SG, Laughlin TM, Kokayeff A, West EE, Adhikari SM, Wan Y, Mogil JS. Heritability of nociception III Genetic relationships among commonly used assays of nociception and hypersensitivity. Pain. 2002; 97(1-2):75-86. [PubMed: 12031781]

7. Diatchenko L, Slade GD, Nackley AG, Bhalang K, Sigurdsson A, Belfer I, Goldman D, Xu K, Shabalina SA, Shagin D, Max MB, Makarov SS, Maixner W. Genetic basis for individual variations in pain perception and the development of a chronic pain condition. Hum. Mol. Genet. 2005; 14(1): 135-143. [PubMed: 15537663]

8. Nackley AG, Tan KS, Fecho K, Flood P, Diatchenko L, Maixner W. Catechol-O-methyltransferase inhibition increases pain sensitivity through activation of both beta2- and beta3-adrenergic receptors. Pain. 2007; 128(3):199-208. [PubMed: 17084978]

9. Pertovaara A, Wei H, Kalmari J, Ruotsalainen M. Pain behavior and response properties of spinal dorsal horn neurons following experimental diabetic neuropathy in the rat: modulation by nitecapone, a COMT inhibitor with antioxidant properties. Exp. Neurol. 2001; 167(2):425-434. [PubMed: 11161631]

10. Jacobsen LM, Eriksen GS, Pedersen LM, Gjerstad J. Catechol-O-methyltransferase (COMT) inhibition reduces spinal nociceptive activity. Neurosci. Lett. 2010; 473(3):212-215. [PubMed: 20219633]

11. Kambur O, Mannisto PT. Catechol-O-methyltransferase and pain. Int Rev Neurobiol. 95:227-79. [PubMed: 21095465]

12. Scholz J, Woolf CJ. Can we conquer pain? Nat. Neurosci. 2002; 5(Suppl):1062-1067. [PubMed: 12403987]

13. Treede RD, Jensen TS, Campbell JN, Cruccu G, Dostrovsky JO, Griffin JW, Hansson P, Hughes R, Nurmikko T, Serra J. Neuropathic pain: redefinition and a grading system for clinical and research purposes. Neurology. 2008; 70(18):1630-1635. [PubMed: 18003941]

14. Papaleo F, Crawley JN, Song J, Lipska BK, Pickel J, Weinberger DR, Chen J. Genetic dissection of the role of catechol-O-methyltransferase in cognition and stress reactivity in mice. J. Neurosci. 2008; 28(35):8709-8723. [PubMed: 18753372] 
15. Weinshilboum R, Raymond F. Variations in Catechol-O-Methyltransferase Activity In Inbred Strains of Rats. Neuropharmacology. 1977; 16:703-706. [PubMed: 304191]

16. Lariviere WR, Sattar MA, Melzack R. Inflammation-susceptible Lewis rats show less sensitivity than resistant Fischer rats in the formalin inflammatory pain test and with repeated thermal testing. J. Neurophysiol. 2006; 95(5):2889-2897. [PubMed: 16452262]

17. Lachman HM, Papolos DF, Saito T, Yu YM, Szumlanski CL, Weinshilboum RM. Human catechol-O-methyltransferase pharmacogenetics: description of a functional polymorphism and its potential application to neuropsychiatric disorders. Pharmacogenetics. 1996; 6(3):243-250. [PubMed: 8807664]

18. Scanlon PD, Raymond FA, Weinshilboum RM. Catechol-O-methyltransferase: thermolabile enzyme in erythrocytes of subjects homozygous for allele for low activity. Science. 1979; 203(4375):63-65. [PubMed: 758679]

19. Spielman RS, Weinshilboum RM. Genetics of red cell COMT activity: analysis of thermal stability family data. Am. J. Med. Genet. 1981; 10(3):279-290. [PubMed: 7304673]

20. Lotta T, Vidgren J, Tilgmann C, Ulmanen I, Melen K, Julkunen I, Taskinen J. Kinetics of human soluble and membrane-bound catechol O-methyltransferase: a revised mechanism and description of the thermolabile variant of the enzyme. Biochemistry. 1995; 34(13):4202-4210. [PubMed: 7703232]

21. Mannisto PT, Kaakkola S. Catechol-O-methyltransferase (COMT): biochemistry, molecular biology, pharmacology, and clinical efficacy of the new selective COMT inhibitors. Pharmacol. Rev. 1999; 51(4):593-628. [PubMed: 10581325]

22. Zubieta JK, Heitzeg MM, Smith YR, Bueller JA, Xu K, Xu Y, Koeppe RA, Stohler CS, Goldman D. COMT val158met genotype affects mu-pioid neurotransmitter responses to a pain stressor. Science. 2003; 299(5610):1240-1243. [PubMed: 12595695]

23. Belfer I, Segall S. COMT genetic variants and pain. Drugs Today (Barc). 47(6):457-67. [PubMed: 21695287]

24. Andersen S, Skorpen F. Variation in the COMT gene: implications for pain perception and pain treatment. Pharmacogenomics. 2009; 10(4):669-684. [PubMed: 19374521]

25. Diatchenko L, Nackley AG, Slade GD, Bhalang K, Belfer I, Max MB, Goldman D, Maixner W. Catechol-O-methyltransferase gene polymorphisms are associated with multiple pain-evoking stimuli. Pain. 2006; 125(3):216-224. [PubMed: 16837133]

26. George SZ, Dover GC, Wallace MR, Sack BK, Herbstman DM, Aydog E, Fillingim RB. Biopsychosocial influence on exercise-induced delayed onset muscle soreness at the shoulder: pain catastrophizing catechol-o-methyltransferase (COMT) diplotype predict pain ratings. Clin. J. Pain. 2008; 24(9):793-801. [PubMed: 18936597]

27. Mobascher A, Brinkmeyer J, Thiele H, Toliat MR, Steffens M, Warbrick T, Musso F, Wittsack HJ, Saleh A, Schnitzler A, Winterer G. The val158met polymorphism of human catechol-Omethyltransferase (COMT) affects anterior cingulate cortex activation in response to painful laser stimulation. Mol. Pain. 2010; 6(1):32. [PubMed: 20509977]

28. Evaskus DS, Laskin DM. A biochemical measure of stress in patients with myofascial paindysfunction syndrome. J. Dent. Res. 1972; 51(5):1464-1466. [PubMed: 4506573]

29. Marbach JJ, Levitt M. Erythrocyte catechol-O-methyltransferase activity in facial pain patients. J. Dent. Res. 1976; 55(4):711. [PubMed: 1064628]

30. Alstergren P, Ernberg M, Kvarnstrom M, Kopp S. Interleukin-1beta in synovial fluid from the arthritic temporomandibular joint its relation to pain mobility and anterior open bite. J. Oral Maxillofac. Surg. 1998; 56(9):1059-1065. discussion 1066. [PubMed: 9734768]

31. Takahashi T, Kondoh T, Fukuda M, Yamazaki Y, Toyosaki T, Suzuki R. Proinflammatory cytokines detectable in synovial fluids from patients with temporomandibular disorders. Oral Surg. Oral Med. Oral Pathol. Oral Radiol. Endod. 1998; 85(2):135-141. [PubMed: 9503445]

32. Alstergren P. Cytokines in temporomandibular joint arthritis. Oral Dis. 2000; 6(6):331-334. [PubMed: 11355265]

33. Suzuki T, Segami N, Nishimura M, Sato J, Nojima T. Bradykinin expression in synovial tissues and synovial fluids obtained from patients with internal derangement of the temporomandibular joint. Cranio. 2003; 21(4):265-270. [PubMed: 14620699] 
34. George SZ, Wallace MR, Wright TW, Moser MW, Greenfield WH 3rd, Sack BK, Herbstman DM, Fillingim RB. Evidence for a biopsychosocial influence on shoulder pain: pain catastrophizing and catechol-O-methyltransferase (COMT) diplotype predict clinical pain ratings. Pain. 2008; 136(12):53-61. [PubMed: 17686583]

35. D'Anto V, Michelotti A, Esposito L, Zagari A, Liguori R, Sacchetti L. Nonsynonimous mutation of catechol-O-methyl-transferase (COMT) gene in a patient with temporomandibular disorder. Prog. Orthod. 2010; 11(2):174-179. [PubMed: 20974455]

36. Williams DA, Clauw DJ. Understanding fibromyalgia: lessons from the broader pain research community. J. Pain. 2009; 10(8):777-791. [PubMed: 19638325]

37. Vargas-Alarcon G, Fragoso JM, Cruz-Robles D, Vargas A, Lao-Villadoniga JI, Garcia-Fructuoso F, Ramos-Kuri M, Hernandez F, Springall R, Bojalil R, Vallejo M, Martinez-Lavin M. CatecholO-methyltransferase gene haplotypes in Mexican and Spanish patients with fibromyalgia. Arthritis Res. Ther. 2007; 9(5):R110. [PubMed: 17961261]

38. Cohen H, Neumann L, Glazer Y, Ebstein RP, Buskila D. The relationship between a common catechol-O-methyltransferase (COMT) polymorphism val(158) met and fibromyalgia. Clin. Exp. Rheumatol. 2009; 27(5 Suppl 56):S51-S56. [PubMed: 20074440]

39. Barbosa FR, Matsuda JB, Mazucato M, de Castro Franca S, Zingaretti SM, da Silva LM, MartinezRossi NM, Junior MF, Marins M, Fachin AL. Influence of catechol-O-methyltransferase (COMT) gene polymorphisms in pain sensibility of Brazilian fibromialgia patients. Rheumatol Int. 2010

40. Matsuda JB, Barbosa FR, Morel LJ, Franca Sde C, Zingaretti SM, da Silva LM, Pereira AM, Marins M, Fachin AL. Serotonin receptor (5-HT 2A) and catechol-O-methyltransferase (COMT) gene polymorphisms: triggers of fibromyalgia? Rev. Bras. Reumatol. 2010; 50(2):141-149. [PubMed: 21125150]

41. Josep Garcia-Fructuoso F, Ignacio Lao-Villadoniga J, Beyer K, Santos C. [Relationship between COMT gene and genotypes severity of fibromyalgia]. Reumatol. Clin. 2006; 2(4):168-172. [PubMed: 21794324]

42. Gursoy S, Erdal E, Herken H, Madenci E, Alasehirli B, Erdal N. Significance of catechol-Omethyltransferase gene polymorphism in fibromyalgia syndrome. Rheumatol. Int. 2003; 23(3): 104-107. [PubMed: 12739038]

43. Finan PH, Zautra AJ, Davis MC, Lemery-Chalfant K, Covault J, Tennen H. COMT moderates the relation of daily maladaptive coping and pain in fibromyalgia. Pain. 2011; 152(2):300-307. [PubMed: 21130573]

44. van Meurs JB, Uitterlinden AG, Stolk L, Kerkhof HJ, Hofman A, Pols HA, Bierma-Zeinstra SM. A functional polymorphism in the catechol-O-methyltransferase gene is associated with osteoarthritis-related pain. Arthritis Rheum. 2009; 60(2):628-629. [PubMed: 19180497]

45. Lee PJ, Delaney P, Keogh J, Sleeman D, Shorten GD. Catecholamine-o-methyltransferase polymorphisms are associated with postoperative pain intensity. Clin. J. Pain. 2011; 27(2):93-101. [PubMed: 20842020]

46. Fernandez-de-Las-Penas C, Fernandez-Lao C, Cantarero-Villanueva I, Ambite-Quesada S, RivasMartinez I, Del MoralAvila R, Arroyo-Morales M. Catechol-O-methyltransferase genotype (Val158met) modulates cancer-related fatigue and pain sensitivity in breast cancer survivors. Breast Cancer Res. Treat. 2011 Sep 4. [Epub ahead of print].

47. Fernandez DEL-PC, Ambite-Quesada S, Rivas-Martinez I, Ortega-Santiago R, AI DE-L-L-R, Fernandez-Mayoralas DM, Pareja JA. Genetic Contribution of Catechol-O-Methyltransferase Polymorphism (Val158Met) in Children With Chronic Tension-Type Headache. Pediatr. Res. 2011; 70(4):395-399. [PubMed: 21691248]

48. Grossman ML, Basbaum AI, Fields HL. Afferent efferent connections of the rat tail flick reflex (a model used to analyze pain control mechanisms). J. Comp. Neurol. 1982; 206(1):9-16. [PubMed: 7096630]

49. Irwin S, Houde RW, Bennett DR, Hendershot LC, Seevers MH. The effects of morphine methadone and meperidine on some reflex responses of spinal animals to nociceptive stimulation. J. Pharmacol. Exp. Ther. 1951; 101(2):132-143. [PubMed: 14814606] 
50. Iyengar S, Webster AA, Hemrick-Luecke SK, Xu JY, Simmons RM. Efficacy of duloxetine, a potent balanced serotonin-norepinephrine reuptake inhibitor in persistent pain models in rats. J. Pharmacol. Exp. Ther. 2004; 311(2):576-584. [PubMed: 15254142]

51. Tammimaki A, Kaenmaki M, Kambur O, Kulesskaya N, Keisala T, Karvonen E, Garcia-Horsman JA, Rauvala H, Mannisto PT. of S-COMT deficiency on behavior and extracellular brain dopamine concentrations in mice. Psychopharmacology (Berl.). 2010; 211(4):389-401. [PubMed: 20617305]

52. Merskey, H. Pain Terms, A Current List with Definitions and Notes on Usage. IASP Press: Seattle; 1994.

53. Levine JD, Taiwo YO, Collins SD, Tam JK. Noradrenaline hyperalgesia is mediated through interaction with sympathetic postganglionic neurone terminals rather than activation of primary afferent nociceptors. Nature. 1986; 323(6084):158-160. [PubMed: 3748187]

54. Sato J, Perl ER. Adrenergic excitation of cutaneous pain receptors induced by peripheral nerve injury. Science. 1991; 251(5001):1608-1610. [PubMed: 2011742]

55. Khasar SG, Green PG, Chou B, Levine JD. Peripheral nociceptive effects of alpha 2-adrenergic receptor agonists in the rat. Neuroscience. 1995; 66(2):427-432. [PubMed: 7477883]

56. Khasar SG, McCarter G, Levine JD. Epinephrine produces a beta-adrenergic receptor-mediated mechanical hyperalgesiain vitro sensitization of rat nociceptors. J. Neurophysiol. 1999; 81(3): 1104-1112. [PubMed: 10085337]

57. Khasar SG, Lin YH, Martin A, Dadgar J, McMahon T, Wang D, Hundle B, Aley KO, Isenberg W, McCarter G, Green PG, Hodge CW, Levine JD, Messing RO. A novel nociceptor signaling pathway revealed in protein kinase C epsilon mutant mice. Neuron. 1999; 24(1):253-260. [PubMed: 10677042]

58. Aley KO, Martin A, McMahon T, Mok J, Levine JD, Messing RO. Nociceptor sensitization by extracellular signalregulated kinases. J. Neurosci. 2001; 21(17):6933-6939. [PubMed: 11517280]

59. Dina OA, Aley KO, Isenberg W, Messing RO, Levine JD. Sex hormones regulate the contribution of PKCepsilon and PKA signalling in inflammatory pain in the rat. Eur. J. Neurosci. 2001; 13(12): 2227-2233. [PubMed: 11454025]

60. Khasar SG, Miao FJ, Gear RW, Green PG, Levine JD. Vagal modulation of bradykinin-induced mechanical hyperalgesia in the female rat. J. Pain. 2003; 4(5):278-283. [PubMed: 14622697]

61. Khasar SG, Dina OA, Green PG, Levine JD. Estrogen regulates adrenal medullary function producing sexual dimorphism in nociceptive threshold and beta-adrenergic receptor-mediated hyperalgesia in the rat. Eur. J. Neurosci. 2005; 21(12):3379-3386. [PubMed: 16026475]

62. Connell FG VII. Local Anaesthesia. Ann. Surg. 1903; 38(6):825-842. [PubMed: 17861395]

63. Davis KD, Treede RD, Raja SN, Meyer RA, Campbell JN. Topical application of clonidine relieves hyperalgesia in patients with sympathetically maintained pain. Pain. 1991; 47(3):309-317. [PubMed: 1664508]

64. Janssen SA, Arntz A, Bouts S. Anxiety and pain: epinephrineinduced hyperalgesia and attentional influences. Pain. 1998; 76(3):309-316. [PubMed: 9718249]

65. Drummond PD. Noradrenaline increases hyperalgesia to heat in skin sensitized by capsaicin. Pain. 1995; 60(3):311-315. [PubMed: 7596627]

66. Drummond PD, Skipworth S, Finch PM. alpha 1-adrenoceptors in normal and hyperalgesic human skin. Clin. Sci.(Lond.). 1996; 91(1):73-77. [PubMed: 8774263]

67. Schattschneider J, Zum Buttel I, Binder A, Wasner G, Hedderich J, Baron R. Mechanisms of adrenosensitivity in capsaicin induced hyperalgesia. Eur. J. Pain. 2007; 11(7):756-763. [PubMed: 17234439]

68. Elfering A, Grebner S, Gerber H, Semmer NK. Workplace observation of work stressors, catecholamines and musculoskeletal pain among male employees. Scand. J. Work Environ. Health. 2008; 34(5):337-344. [PubMed: 18853065]

69. Elfering A, Grebner S, Semmer NK, Gerber H. Time control catecholamines back pain among young nurses. Scand. J. Work Environ. Health. 2002; 28(6):386-393. [PubMed: 12539798]

70. Weber H. Uber Anasthesie durch Adrenalin. Verhandlungen der Deutschen Gesellschaft für Innere Medizin. 1904; 21:616-619. 
71. Buscaino, VMaCP. Terepia adrenergica del dolori. Rassegna internazionale di clinica e terapia. 1940; 21:691-695.

72. Collins JG, Kitahata LM, Matsumoto M, Homma E, Suzukawa M. Spinally administered epinephrine suppresses noxiously evoked activity of WDR neurons in the dorsal horn of the spinal cord. Anesthesiology. 1984; 60(4):269-275. [PubMed: 6322616]

73. Reddy SV, Maderdrut JL, Yaksh TL. Spinal cord pharmacology of adrenergic agonist-mediated antinociception. J. Pharmacol. Exp.Ther. 1980; 213(3):525-533. [PubMed: 6110767]

74. Howe JR, Yaksh TL. Changes in sensitivity to intrathecal norepinephrine and serotonin after 6hydroxydopamine (6-OHDA), 5,6-dihydroxytryptamine (5,6-DHT) or repeated monoamine administration. J. Pharmacol. Exp. Ther. 1982; 220(2):311-321. [PubMed: 6120226]

75. Reddy SV, Yaksh TL. Spinal noradrenergic terminal system mediates antinociception. Brain Res. 1980; 189(2):391-401. [PubMed: 6245762]

76. Kuraishi Y, Harada Y, Takagi H. Noradrenaline regulation of pain-transmission in the spinal cord mediated by alphaadrenoceptors. Brain Res. 1979; 174(2):333-336. [PubMed: 226222]

77. Bray KE, Katz S, Adriani J. The effect of vasoconstrictors upon the duration of spinal anesthesia; a controlled study in man. Anesthesiology. 1949; 10(1):40-53. [PubMed: 18107353]

78. Bonica JJ, Backup PH, Pratt WH. The use of vasoconstrictors to prolong spinal anesthesia. Anesthesiology. 1951; 12(4):431-441. [PubMed: 14847226]

79. Yoshimura M, Furue H. Mechanisms for the anti-nociceptive actions of the descending noradrenergic and serotonergic systems in the spinal cord. J. Pharmacol. Sci. 2006; 101(2):107117. [PubMed: 16766858]

80. Concepcion M, Maddi R, Francis D, Rocco AG, Murray E, Covino BG. Vasoconstrictors in spinal anesthesia with tetracaine-- a comparison of epinephrine and phenylephrine. Anesth. Analg. 1984; 63(2):134-138. [PubMed: 6362490]

81. Vaida GT, Moss P, Capan LM, Turndorf H. Prolongation of lidocaine spinal anesthesia with phenylephrine. Anesth. Analg. 1986; 65(7):781-785. [PubMed: 3717618]

82. Sagen J, Pappas GD, Perlow MJ. Adrenal medullary tissue transplants in the rat spinal cord reduce pain sensitivity. Brain Res. 1986; 384(1):189-194. [PubMed: 3790994]

83. Sagen J, Pappas GD, Pollard HB. Analgesia induced by isolated bovine chromaffin cells implanted in rat spinal cord. Proc. Natl. Acad. Sci. USA. 1986; 83(19):7522-7526. [PubMed: 3463981]

84. Sagen J, Winker MA, Proudfit HK. Hypoalgesia induced by the local injection of phentolamine in the nucleus raphe magnus: blockade by depletion of spinal cord monoamines. Pain. $1983 ; 16(3)$ : 253-263. [PubMed: 6310470]

85. Proudfit HK, Yaksh TL. Nociceptive threshold and morphone analgesia: alterations following the intrthecal administration of 6-hydroxydopamine and 5,6-dihydroxytryptamine. Soc. Neurosci. Abst. 1980; 6:433.

86. Pertovaara A. Noradrenergic pain modulation. Prog. Neurobiol. 2006; 80(2):53-83. [PubMed: 17030082]

87. Dogrul A, Coskun I, Uzbay T. The contribution of alpha-1 alpha-2 adrenoceptors in peripheral imidazoline adrenoceptor agonist-induced nociception. Analg. Anesth. 2006; 103(2):471-477.

88. Meisner JG, Waldron JB, Sawynok J. Alpha1-adrenergic receptors augment P2 23 receptormediated nociceptive responses in the uninjured state. J. Pain. 2007; 8(7):556-562. [PubMed: 17512257]

89. Fuchs PN, Meyer RA, Raja SN. Heat, but not mechanical hyperalgesia, following adrenergic injections in normal human skin. Pain. 2001; 90(1-2):15-23. [PubMed: 11166966]

90. Drummond PD. alpha(1)-Adrenoceptors augment thermal hyperalgesia in mildly burnt skin. Eur. J. Pain. 2009; 13(3):273-279. [PubMed: 18524654]

91. Chan AK, Cheung CW, Chong YK. Alpha-2 agonists in acute pain management. Expert Opin. Pharmacother. 2010; 11(17):2849-2868. [PubMed: 20707597]

92. Pertovaara A, Wei H. Attenuation of ascending nociceptive signals to the rostroventromedial medulla induced by a novel alpha2-adrenoceptor agonist, MPV-2426, following intrathecal application in neuropathic rats. Anesthesiology. 2000; 92(4):1082-1092. [PubMed: 10754629] 
93. Pertovaara A, Kauppila T, Tukeva T. The effect of medetomidine an alpha 2-adrenoceptor agonist in various pain tests. Eur. J. Pharmacol. 1990; 179(3):323-328. [PubMed: 1973106]

94. Pertovaara A, Kauppila T, Jyvasjarvi E, Kalso E. Involvement of supraspinal and spinal segmental alpha-2-adrenergic mechanisms in the medetomidine-induced antinociception. Neuroscience. 1991; 44(3):705-714. [PubMed: 1684411]

95. Duflo F, Li X, Bantel C, Pancaro C, Vincler M, Eisenach JC. Peripheral nerve injury alters the alpha2 adrenoceptor subtype activated by clonidine for analgesia. Anesthesiology. 2002; 97(3): 636-641. [PubMed: 12218531]

96. Gyires K, Zadori ZS, Shujaa N, Al-Khrasani M, Pap B, Mozes MM, Matyus P. Pharmacological analysis of alpha(2)-adrenoceptor subtypes mediating analgesic, anti-inflammatory and gastroprotective actions. Inflammopharmacology. 2009; 17(3):171-179. [PubMed: 19526313]

97. Danzebrink RM, Gebhart GF. Antinociceptive effects of intrathecal adrenoceptor agonists in a rat model of visceral nociception. J. Pharmacol. Exp. Ther. 1990; 253(2):698-705. [PubMed: 1971018]

98. Yaksh TL, Reddy SV. Studies in the primate on the analgetic effects associated with intrathecal actions of opiates, alphaadrenergic agonists and baclofen. Anesthesiology. 1981; 54(6):451-467. [PubMed: 6112935]

99. Buerkle H, Yaksh TL. Pharmacological evidence for different alpha 2-adrenergic receptor sites mediating analgesia and sedation in the rat. Br. J. Anaesth. 1998; 81(2):208-215. [PubMed: 9813525]

100. Graham BA, Hammond DL, Proudfit HK. Synergistic interactions between two alpha(2)adrenoceptor agonists, dexmedetomidine and ST-91, in two substrains of Sprague-Dawley rats. Pain. 2000; 85(1-2):135-143. [PubMed: 10692612]

101. Xu M, Kontinen VK, Kalso E. Effects of radolmidine, a novel alpha2 -adrenergic agonist compared with dexmedetomidine in different pain models in the rat. Anesthesiology. 2000; 93(2):473-481. [PubMed: 10910498]

102. Zeng W, Chen X, Dohi S. Antinociceptive synergistic interaction between clonidine and ouabain on thermal nociceptive tests in the rat. J. Pain. 2007; 8(12):983-988. [PubMed: 17892975]

103. Lakhlani PP, MacMillan LB, Guo TZ, McCool BA, Lovinger DM, Maze M, Limbird LE. Substitution of a mutant alpha2a-adrenergic receptor via "hit run" gene targeting reveals the role of this subtype insedative, analgesic and anestheticsparing responses in vivo. Proc. Natl. Acad. Sci. USA. 1997; 94(18):9950-9955. [PubMed: 9275232]

104. Sherman S, Loomis C, Milne B, Cervenko F. Prolonged spinal analgesia in the rat with the alphaadrenoceptor agonist oxymetazoline. Eur. J. Pharmacol. 1987; 140(1):25-32. [PubMed: 3622622]

105. Womer DE, Shannon HE. Pharmacologic reversal of pertussis toxin-induced thermal allodynia in mice. Neuropharmacology. 2000; 39(10):1732-1739. [PubMed: 10884555]

106. Ushiyama K, Kimura E, Kikuchi H, Mabuchi G. Effects of nitroglycerin and propranolol on angina pectoris induced by intravenous infusion of isoproterenol. Isr. J. Med. Sci. 1969; 5(4): 736-737. [PubMed: 4980552]

107. Ren Y, Zou X, Fang L, Lin Q. Sympathetic modulation of activity in Adelta- and C-primary nociceptive afferents after intradermal injection of capsaicin in rats J. Neurophysiol. 2005; 93(1): 365-377.

108. Mokhtari G, Shakiba M, Ghodsi S, Farzan A, Heidari Nejad S, Esmaeili S. Effect of terazosin on lower urinary tract symptoms and pain due to double-J stent: a double-blind placebo-controlled randomized clinical trial. Urol. Int. 2011; 87(1):19-22. [PubMed: 21597261]

109. Korzeniewska-Rybicka I, Plaznik A. Role of serotonergic and noradrenergic systems in a model of visceral pain. Pol. J. Pharmacol. 2001; 53(5):475-480. [PubMed: 11990065]

110. Sagen J, Proudfit HK. Effect of intrathecally administered noradrenergic antagonists on nociception in the rat. Brain Res. 1984; 310(2):295-301. [PubMed: 6548399]

111. Nogueira-Neto Fde S, Amorim RL, Brigatte P, Picolo G, Ferreira WA Jr. Gutierrez VP, Conceicao IM, Della-Casa MS, Takahira RK, Nicoletti JL, Cury Y. The analgesic effect of crotoxin on neuropathic pain is mediated by central muscarinic receptors and 5-lipoxygenasederived mediators. Pharmacol. Biochem. Behav. 2008; 91(2):252-260. [PubMed: 18778727] 
112. Park CH, Lee HG, Lee SH, Chung CW, Yoon MH. The role of adrenergic and cholinergic receptors on the antinociception of sildenafil in the spinal cord of rats. Neurosci. Lett. 2011; 502(2):99-102. [PubMed: 21820036]

113. Proudfit HK, Hammond DL. Alterations in nociceptive threshold and morphine-induced analgesia produced by intrathecally administered amine antagonists. Brain. Res. 1981; 218(1-2):393-399. [PubMed: 6895046]

114. Dias QM, Crespilho SF, Silveira JW, Prado WA. Muscarinic the spinal mediation of stimulationinduced antinociception from the pedunculopontine tegmental nucleus in the rat. Pharmacol. Biochem. Behav. 2009; 92(3):488-494. [PubMed: 19463264]

115. Yaksh TL, Pogrel JW, Lee YW, Chaplan SR. Reversal of nerve ligation-induced allodynia by spinal alpha-2 adrenoceptor agonists. J. Pharmacol. Exp. Ther. 1995; 272(1):207-214. [PubMed: 7815335]

116. Kaumann . AJ Yohimbine rauwolscine inhibit 5-hydroxytryptamine-induced contraction of large coronary arteries of calf through blockade of 5 HT2 receptors. Naunyn Schmiedebergs Arch. Pharmacol. 1983; 323(2):149-154. [PubMed: 6136920]

117. Millan MJ, Newman-Tancredi A, Audinot V, Cussac D, Lejeune F, Nicolas JP, Coge F, Galizzi JP, Boutin JA, Rivet JM, Dekeyne A, Gobert A. Agonist antagonist actions of yohimbine as compared to fluparoxan at alpha(2)-adrenergic receptors (AR)s, serotonin (5-HT)(1A), 5HT(1B), 5-HT(1D), dopamine D(2), D(3) receptors Significance for the modulation of frontocortical monoaminergic transmission and depressive states. Synapse. 2000; 35(2):79-95. [PubMed: 10611634]

118. Baxter GS, Murphy OE, Blackburn TP. Further characterization of 5-hydroxytryptamine receptors (putative 5-HT2B) in rat stomach fundus longitudinal muscle. Br. J. Pharmacol. 1994; 112(1):323-331. [PubMed: 8032658]

119. Tamayo L, Rifo J, Contreras E. Influence of adrenergic and cholinergic mechanisms in baclofen induced analgesia. Genet. Pharmacol. 1988; 19(1):87-89.

120. Chen YW, Chu CC, Chen YC, Hung CH, Wang JJ. Intrathecal propranolol displays long-acting spinal anesthesia with a more sensory-selective action over motor blockade in rats. Eur. J. Pharmacol. 2011; 667(1-3):208-214. [PubMed: 21699891]

121. Light KC, Bragdon EE, Grewen KM, Brownley KA, Girdler SS, Maixner W. Adrenergic dysregulation pain with without acute beta-blockade in women with fibromyalgia and temporomandibular disorder. J. Pain. 2009; 10(5):542-552. [PubMed: 19411061]

122. Wood PB, Kablinger AS, Caldito GS. Open trial of pindolol in the treatment of fibromyalgia. Ann. Pharmacother. 2005; 39(11):1812-1816. [PubMed: 16219901]

123. Tchivileva IE, Lim PF, Smith SB, Slade GD, Diatchenko L, McLean SA, Maixner W. Effect of catechol-O-methyltransferase polymorphism on response to propranolol therapy in chronic musculoskeletal pain: a randomized, doubleblind, placebo-controlled, crossover pilot study. Pharmacogenet. Genomics. 2010; 20(4):239-248. [PubMed: 20216107]

124. Neil MJ. Clonidine: Clinical Pharmacology and Therapeutic Use in Pain Management. Curr. Clin. Pharmacol. 2011

125. Ramsdale DR, Faragher EB, Bennett DH, Bray CL, Ward C, Cruickshank JM, Yusuf S, Sleight P. Ischemic pain relief in patients with acute myocardial infarction by intravenous atenolol. Am. Heart J. 1982; 103(4 Pt 1):459-467. [PubMed: 6121479]

126. Everts B, Karlson BW, Herlitz J, Abdon NJ, Hedner T. Effects pharmacokinetics of high dose metoprolol on chest pain in patients with suspected or definite acute myocardial infarction. Eur. J. Clin. Pharmacol. 1997; 53(1):23-31. [PubMed: 9349926]

127. Dworkin RH, O'Connor AB, Backonja M, Farrar JT, Finnerup NB, Jensen TS, Kalso EA, Loeser JD, Miaskowski C, Nurmikko TJ, Portenoy RK, Rice AS, Stacey BR, Treede RD, Turk DC, Wallace MS. Pharmacologic management of neuropathic pain: evidence-based recommendations. Pain. 2007; 132(3):237-251. [PubMed: 17920770]

128. Naleschinski D, Baron R. Complex regional pain syndrome type I: neuropathic or not? Curr. Pain Head. Rep. 14(3):196-202.

129. Cervero F, Laird JMA. One pain or many pains? A new look at pain mechanisms. News Physiol. Sci. 1991; 6:268-273. 
130. Treede RD, Meyer RA, Raja SN, Campbell JN. Peripheral central mechanisms of cutaneous hyperalgesia. Prog. Neurobiol. 1992; 38(4):397-421. [PubMed: 1574584]

131. Osterberg A, Boivie J, Thuomas KA. Central pain in multiple sclerosis--prevalence and clinical characteristics. Eur. J. Pain. 2005; 9(5):531-542. [PubMed: 16139182]

132. Scadding, JW.; Koltzenburg, M. Neuropathic pain. Churchill Livingstone: Edinburgh; 2005. p. 973-999.

133. Finnerup NB, Otto M, McQuay HJ, Jensen TS, Sindrup SH. Algorithm for neuropathic pain treatment: an evidence based proposal. Pain. 2005; 118(3):289-305. [PubMed: 16213659]

134. Herradon G, Ezquerra L, Nguyen T, Wang C, Siso A, Franklin B, Dilorenzo L, Rossenfeld J, Alguacil LF, SilosSantiago I. Changes in BDNF gene expression correlate with rat strain differences in neuropathic pain. Neurosci. Lett. 2007; 420(3):273-276. [PubMed: 17556103]

135. Herradon G, Ezquerra L, Nguyen T, Wang C, Siso A, Franklin B, Dilorenzo L, Rossenfeld J, Silos-Santiago I, Alguacil LF. Noradrenergic opioidergic alterations in neuropathy in different rat strains. Neurosci. Lett. 2008; 438(2):186-189. [PubMed: 18472331]

136. Fecho K, Valtschanoff JG. Acute inflammatory neuropathic pain in Lewis Fischer rats. J. Neuroendocrinol. 2006; 18(7):504-513. [PubMed: 16774499]

137. Armero P, Muriel C, Santos J, Sanchez-Montero FJ, Rodriguez RE. Gonzalez-Sarmiento RCOMT (Val158Met) polymorphism is not associated to neuropathic pain in a Spanish population. Eur. J. Pain. 2005; 9(3):229-232. [PubMed: 15862471]

138. Coderre TJ, Grimes RW, Melzack R. Deafferentation and chronic pain in animals: an evaluation of evidence suggesting autotomy is related to pain. Pain. 1986; 26(1):61-84. [PubMed: 3526256]

139. Ginzburg R, Seltzer Z. Subarachnoid spinal cord transplantation of adrenal medulla suppresses chronic neuropathic pain behavior in rats. Brain Res. 1990; 523(1):147-150. [PubMed: 2207684]

140. Eaton MJ, Martinez M, Karmally S, Lopez T, Sagen J. Initial characterization of the transplant of immortalized chromaffin cells for the attenuation of chronic neuropathic pain. Cell Transplant. 2000; 9(5):637-656. [PubMed: 11144961]

141. Kim YM, Kwak KH, Lim JO, Baek WY. Reduction of allodynia by intrathecal transplantation of microencapsulated porcine chromaffin cells. Artif. Organs. 2009; 33(3):240-249. [PubMed: 19245523]

142. Jeon Y, Baek WY, Chung SH, Shin N, Kim HR, Lee SA. Cultured human chromaffin cells grafted in spinal subarachnoid space relieves allodynia in a pain rat model. Korean $\mathrm{J}$. Anesthesiol. 2010; 60(5):357-361. [PubMed: 21716909]

143. Kambur O, Talka R, Ansah OB, Kontinen VK, Pertovaara A, Kalso E, Mannisto PT. Inhibitors of catechol-O-methyltransferase sensitize mice to pain. Br. J. Pharmacol. 2010; 161(7):1553-1565. [PubMed: 20726980]

144. Lee DH, Liu X, Kim HT, Chung K, Chung JM. Receptor subtype mediating the adrenergic sensitivity of pain behavior and ectopic discharges in neuropathic Lewis rats. J. Neurophysiol. 1999; 81(5):2226-2233. [PubMed: 10322061]

145. Kim SH, Na HS, Sheen K, Chung JM. Effects of sympathectomy on a rat model of peripheral neuropathy. Pain. 1993; 55(1):85-92. [PubMed: 8278213]

146. Hord AH, Denson DD, Stowe B, Haygood RM. alpha-1 and alpha-2 Adrenergic antagonists relieve thermal hyperalgesia in experimental mononeuropathy from chronic constriction injury. Anesth. Analg. 2001; 92(6):1558-1562. [PubMed: 11375846]

147. Nam TS, Yeon DS, Leem JW, Paik KS. Adrenergic sensitivity of uninjured C-fiber nociceptors in neuropathic rats. Yonsei Med. J. 2000; 41(2):252-257. [PubMed: 10817027]

148. Galer BS. Peak pain relief is delayed and duration of relief is extended following intravenous phentolamine infusion. Preliminary report. Reg. Anesth. 1995; 20(5):444-447. [PubMed: 8519723]

149. Park CH, Yong A, Lee SH. Involvement of selective alpha-2 adrenoreceptor in sympathetically maintained pain. J. Korean Neurosurg. Soc. 2010; 47(6):420-423. [PubMed: 20617085]

150. Byas-Smith MG, Max MB, Muir J, Kingman A. Transdermal clonidine compared to placebo in painful diabetic neuropathy using a two-stage 'enriched enrollment' design. Pain. 1995; 60(3): 267-274. [PubMed: 7596622] 
151. Malmberg AB, Hedley LR, Jasper JR, Hunter JC, Basbaum AI. Contribution of alpha(2) receptor subtypes to nerve injury-induced pain and its regulation by dexmedetomidine. Br. J. Pharmacol. 2001; 132(8):1827-1836. [PubMed: 11309255]

152. Xanthos DN, Coderre TJ. Sympathetic vasoconstrictor antagonism and vasodilatation relieve mechanical allodynia in rats with chronic postischemia pain. J. Pain. 2008; 9(5):423-433. [PubMed: 18262849]

153. Ringkamp M, Grethel EJ, Choi Y, Meyer RA, Raja SN. Mechanical hyperalgesia after spinal nerve ligation in rat is not reversed by intraplantar or systemic administration of adrenergic antagonists. Pain. 1999; 79(2-3):135-141. [PubMed: 10068159]

154. Choi B, Rowbotham MC. Effect of adrenergic receptor activation on post-herpetic neuralgia pain and sensory disturbances. Pain. 1997; 69(1-2):55-63. [PubMed: 9060013]

155. Omiya Y, Yuzurihara M, Suzuki Y, Kase Y, Kono T. Role of alpha2-adrenoceptors in enhancement of antinociceptive effect in diabetic mice. Eur. J. Pharmacol. 2008; 592(1-3):6266. [PubMed: 18625215]

156. Verdugo RJ, Campero M, Ochoa JL. Phentolamine sympathetic block in painful polyneuropathies II Further questioning of the concept of 'sympathetically maintained pain'. Neurology. 1994; 44(6):1010-1014. [PubMed: 8208391]

157. Ossipov MH, Lopez Y, Bian D, Nichols ML, Porreca F. Synergistic antinociceptive interactions of morphine and clonidine in rats with nerve-ligation injury. Anesthesiology. 1997; 86(1):196204. [PubMed: 9009955]

158. Lavand'homme PM, Ma W, De Kock M, Eisenach JC. Perineural alpha(2A)-adrenoceptor activation inhibits spinal cord neuroplasticity and tactile allodynia after nerve injury. Anesthesiology. 2002; 97(4):972-980. [PubMed: 12357167]

159. Leiphart JW, Dills CV, Zikel OM, Kim DL, Levy RM. A comparison of intrathecally administered narcotic and nonnarcotic analgesics for experimental chronic neuropathic pain. J. Neurosurg. 1995; 82(4):595-599. [PubMed: 7897521]

160. Moon DE, Lee DH, Han HC, Xie J, Coggeshall RE, Chung JM. Adrenergic sensitivity of the sensory receptors modulating mechanical allodynia in a rat neuropathic pain model. Pain. 1999; 80(3):589-595. [PubMed: 10342420]

161. Romero-Sandoval A, Eisenach JC. Perineural clonidine reduces mechanical hypersensitivity and cytokine production in established nerve injury. Anesthesiology. 2006; 104(2):351-355. [PubMed: 16436856]

162. Romero-Sandoval A, Bynum T, Eisenach JC. Analgesia induced by perineural clonidine is enhanced in persistent neuritis. Neuroreport. 2007; 18(1):67-71. [PubMed: 17259863]

163. Lavand'homme PM, Eisenach JC. Perioperative administration of the alpha2-adrenoceptor agonist clonidine at the site of nerve injury reduces the development of mechanical hypersensitivity and modulates local cytokine expression. Pain. 2003; 105(1-2):247-254. [PubMed: 14499442]

164. Wei H, Pertovaara A. Spinal pontine alpha2-adrenoceptors have opposite effects on pain-related behavior in the neuropathic rat. Eur. J. Pharmacol. 2006; 551(1-3):41-49. [PubMed: 17027962]

165. Quessy SN, Rowbotham MC. Placebo response in neuropathic pain trials. Pain. 2008; 138(3): 479-483. [PubMed: 18706762]

166. Xu K, Naveri L, Frerichs KU, Hallenbeck JM, Feuerstein G, Davis JN, Siren AL. Extracellular catecholamine levels in rat hippocampus after a selective alpha-2 adrenoceptor antagonist or a selective dopamine uptake inhibitor: evidence for dopamine release from local dopaminergic nerve terminals. J. Pharmacol. Exp. Ther. 1993; 267(1):211-217. [PubMed: 7901393]

167. Choucair-Jaafar N, Yalcin I, Rodeau JL, Waltisperger E, Freund-Mercier MJ, Barrot M. Beta2adrenoceptor agonists alleviate neuropathic allodynia in mice after chronic treatment. Br. J. Pharmacol. 2009; 158(7):1683-1694. [PubMed: 19912227]

168. Yalcin I, Tessier LH, Petit-Demouliere N, Waltisperger E, Hein L, Freund-Mercier MJ, Barrot M. Chronic treatment with agonists of beta(2)-adrenergic receptors in neuropathic pain. Exp. Neurol. 2010; 221(1):115-121. [PubMed: 19840789]

169. Cok OY, Eker HE, Yalcin I, Barrot M, Aribogan A. Is there a place for beta-mimetics in clinical management of neuropathic pain? Salbutamol therapy in six cases. Anesthesiology. 2010; 112(5):1276-1279. [PubMed: 20395826] 
170. Starke K. Alpha-adrenoceptor subclassification. Rev. Physiol. Biochem. Pharmacol. 1981; 88:S199-S236. 


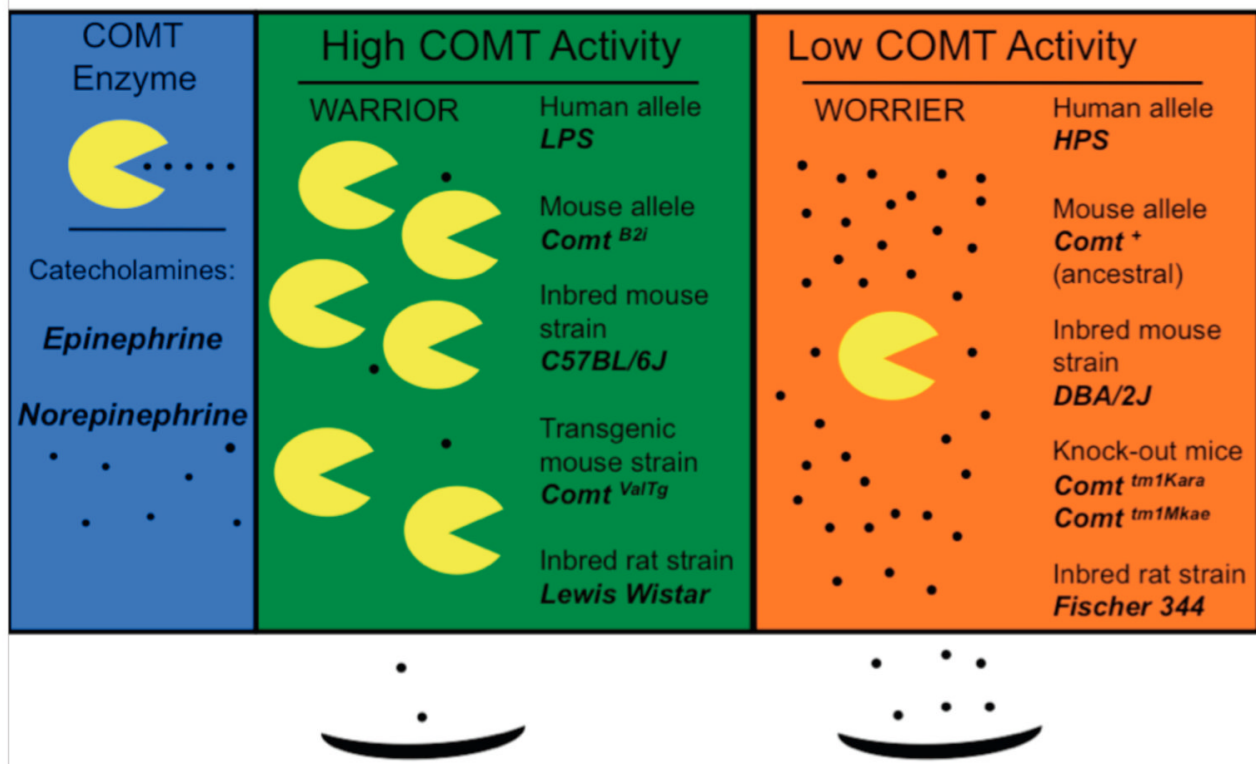

Adrenergic receptor

Adrenergic receptor

b.

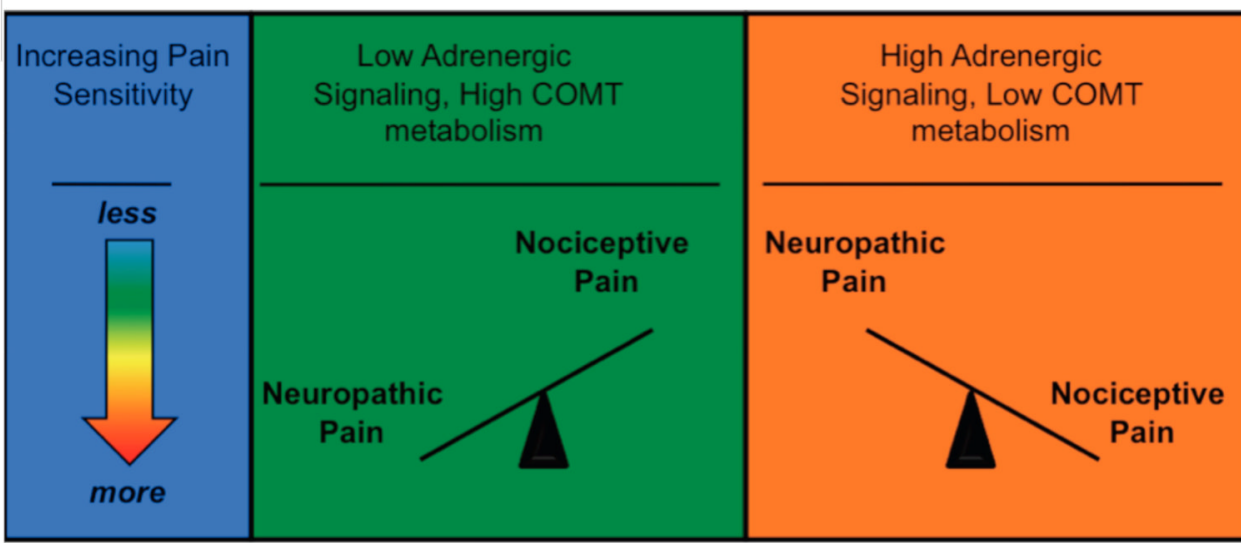

c.

\section{Vulnerable \\ to \\ Neuropathic \\ Pain}
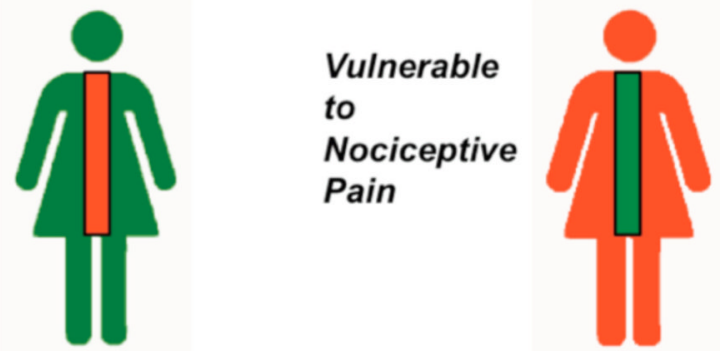

Fig. 1. Model of relationship between COMT activity alleles and pain sensitivity in different pain modalities

a: COMT enzyme is depicted as "pacman" and Epi and NE as small black dots. High COMT activity in human or mouse alleles or in rat strains is assumed to result in less adrenergic signaling. b: Axis between neuropathic pain and nociceptive types of pain is tilted by catecholamine signaling. c: Two models of catecholamine metabolism, with the spinal cord colored to denote increasing or decreasing pain sensitivity. High COMT activity is hypothesized to be a risk factor for neuropathic pain and low COMT activity is hypothesized to be a risk factor for nociceptive pain. 


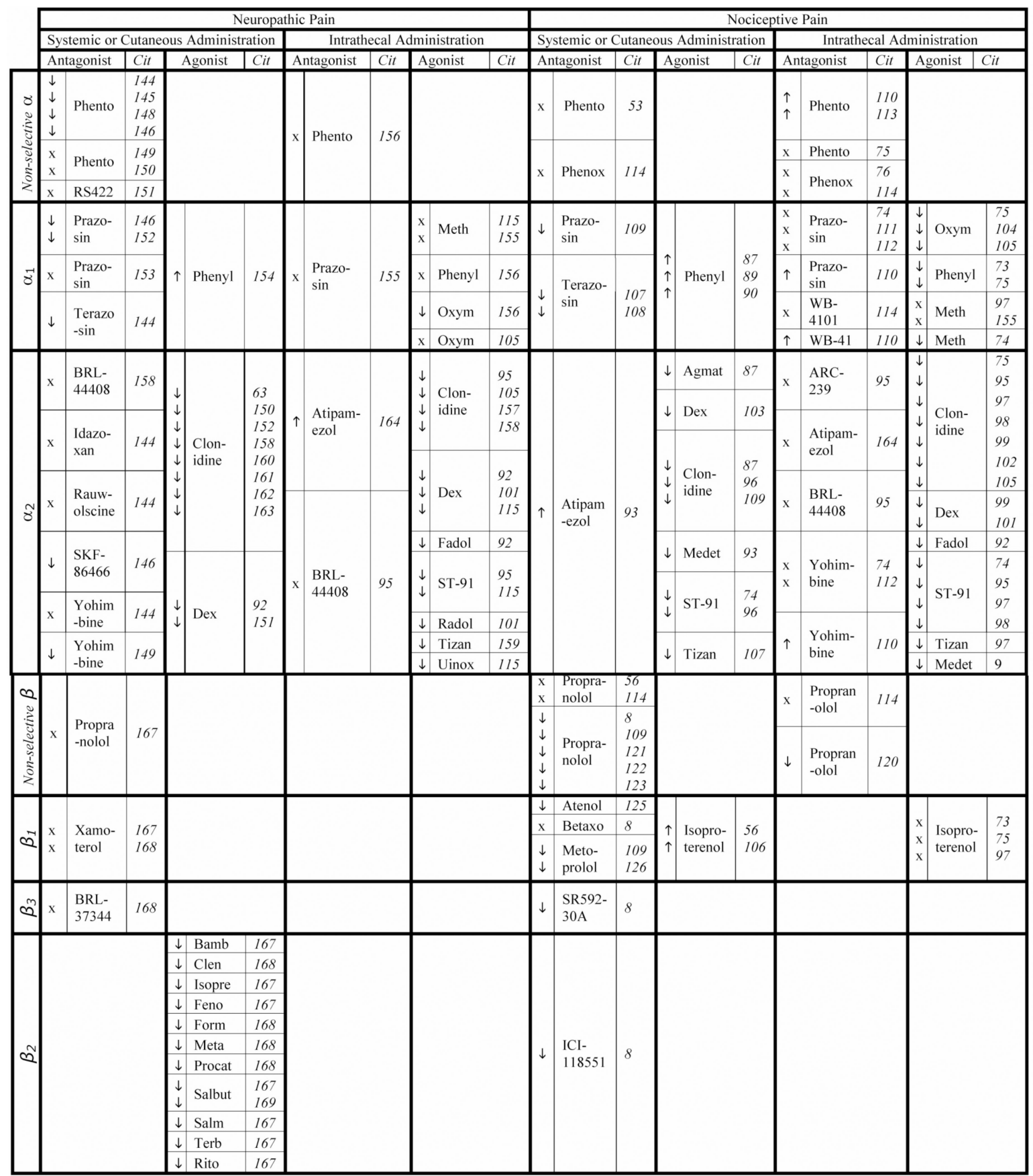

Fig. 2. Summary of Adrenergic Receptors in Neuropathic and Nociceptive types of Pain Arrows pointing upwards indicate increased nociception, $\mathrm{X}$ indicates no change.

Agmat $=$ agmatine $;$ Atenol $=$ atenolol $; \mathbf{B a m b}=$ bambuterol $;$ Betaxo $=$ betaxolol $;$ BRL44 $=$ BRL44408; Clen $=$ clenbuterol; $\mathbf{D e x}=$ dexmedetomidine; Fadol $=$ fadolmidine $; \mathbf{F e n o}=$ fenotero; Form $=$ formoterol; Isopre $=$ isoprenaline; Medet $=$ medetomidine; Meta $=$ metaproterenol; Meth $=$ methoxamine; Oxym $=$ oxymetazoline; Phenox $=$ phenoxybenzamine; Phento $=$ phentolamine $\mathbf{P h e n y l}=$ phenylephrine $;$ Procat $=$ procaterol; Propran $=$ propranolol $; \mathbf{R a d o l}=$ radolmidine $;$ Rito $=$ ritodrine $; \mathbf{R S 4 2 2}=$ RS42206; $\mathbf{S a l b}=$ 
salbutamol; Salm = salmetoral; Terb $=$ terbutaline; Tizan $=$ tizanidine; Uinox = uinoxaline; WB-41= WB-4101. 
Table 1

List of Pharmacologic Agents to Modulate Catecholamine Signaling

\begin{tabular}{|c|c|c|c|}
\hline \multicolumn{2}{|l|}{ Adrenergic Signaling Down $\Downarrow$} & \multicolumn{2}{|l|}{ Adrenergic Signaling UP $\Uparrow$} \\
\hline Compound Type & Examples & Compound Type & Examples \\
\hline COMT Activator & (None yet) & COMT Inhibitors & $\begin{array}{l}\text { Nitecapone } \\
\text { OR } 486\end{array}$ \\
\hline Catecholamine Signaling Decreasing Agents or Drugs & $\begin{array}{l}\text { Guanethidine } \\
\text { Reserpine } \\
\text { 6-OHDA } \\
\text { *Clonidine }\end{array}$ & $\begin{array}{l}\text { Catecholamine Signaling Increasing } \\
\text { Agents or Drugs }\end{array}$ & $\begin{array}{l}\text { Epinephrine } \\
\text { Norepinephrine }\end{array}$ \\
\hline \multicolumn{2}{|l|}{ Adrenergic Antagonists } & \multicolumn{2}{|c|}{ Adrenergic Agonists (effects similar to epinephrine) } \\
\hline$a_{1}$ & $\begin{array}{l}\text { Prazosin } \\
\text { Terazosin }\end{array}$ & $a_{1}$ & $\begin{array}{l}\text { Phenylephrine } \\
\text { Methoxamine }\end{array}$ \\
\hline$a_{2}$ & $\begin{array}{l}\text { Atipamezole } \\
\text { Yohimbine }\end{array}$ & $a_{2}$ & $\begin{array}{l}\text { Clonidine } \\
\text { ST-91 }\end{array}$ \\
\hline$a_{2 A}$ & BRL44408 & $\beta$ & Bambuterol \\
\hline Non-selective $\mathrm{a}$-adrenergic antagonist & $\begin{array}{l}\text { Phentolamine } \\
\text { Phenoxybenzamine }\end{array}$ & $\beta_{1 \text { and } 2}$ & Isoprenaline \\
\hline$\beta_{1}$ & metoprolol & $\beta_{2}$ & $\begin{array}{l}\text { Clenbuterol } \\
\text { Fenoterol } \\
\text { Formoterol } \\
\text { Metaproterenol } \\
\text { Procaterol } \\
\text { Salbutamol } \\
\text { Terbutaline }\end{array}$ \\
\hline$\beta_{2}$ & $\begin{array}{l}\text { ICI } 118,551 \\
\text { Butoxamine }\end{array}$ & $\beta_{3}$ & SR 592308 \\
\hline Non-selective $\beta$-blocker & $\begin{array}{l}\text { Pindolol } \\
\text { Propranalol }\end{array}$ & & \\
\hline
\end{tabular}

Legend: Clonidine decreases peripheral NE release [170]. 
Table 2

A Summary of Adrenergic Signaling Contribution to Pain Perception

\begin{tabular}{|c|c|c|}
\hline Molecule & $\begin{array}{c}\text { Spinal } \\
\text { Nociception }\end{array}$ & $\begin{array}{c}\text { Peripheral } \\
\text { Nociception }\end{array}$ \\
\hline Epi/NE & $\downarrow$ & $\uparrow$ \\
\hline Epi/NE releasing or blocking drug & $\downarrow$ & $\uparrow$ \\
\hline Epi/NE releasing cell or tissue transplant & $\downarrow$ & $*$ \\
\hline Adrenergic Agonist & $\downarrow$ & $\downarrow^{* *}$ \\
\hline Adrenergic Antagonist & $\uparrow$ & $\downarrow^{* *}$ \\
\hline Enzymatic COMT activity & $\uparrow$ & $\downarrow$ \\
\hline
\end{tabular}

* Legend: We have not been able to find in the literature a description of an Epi/NE releasing cell or tissue (chromaffin) transplanted other than the subarachnoid space, the eye, or within regions of the brain.

The (a 2 -adrenergic signaling is generally analgesic and $a_{1}$ and $\beta$-adrenergic signaling is hyperalgesic or analgesic, depending on pain modality. 